\title{
Entrepreneurial activity in ecosystems and in areas of advanced development
}

\author{
Vladimir Smirnov \\ School of Economics and Management, \\ Far Eastern Federal University (FEFU) \\ Vladivostok, Russia \\ smirnov.vp@dvfu.ru
}

\begin{abstract}
Entrepreneurship plays a decisive role in the development of the economy. Expansion of the scale of entrepreneurial activity is carried out in various ways. The first most common method is the spontaneous formation of entrepreneurial ecosystems. Another way is the development by the government of the corresponding economic policy. The Russian state pursues such policy. It establishes a favorable legal regime for the implementation of entrepreneurial and investment activities in selected territories and renders state support to specific areas of such activity or to certain entities. Different authors define the entrepreneurial ecosystem differently. But the entrepreneur always takes a central place in it and plays a leading role in its creation and maintenance. Experts believe that entrepreneurial ecosystems include economic, social, institutional and other important factors and components that have an interactive impact on the creation, discovery and use of entrepreneurial opportunities. With the use of favorable opportunities, entrepreneurs can freely create new capital in various types and forms. On the territories of advanced socioeconomic development, there are no number of important factors and components that contribute to the manifestation of entrepreneurial activity.
\end{abstract}

Keywords- entrepreneurship, the creation of new capital, the ecosystem, the territory of advanced social and economic development.

\section{INTRODUCTION}

Leading economists, politicians and managers develop approaches and express ideas that confirm the decisive role of entrepreneurship in the development of the economy. Entrepreneurship is the process of creating value as a result of the search and realization of favorable opportunities. This process is rightly regarded as an internal source and a key factor in modern economic development.

Expansion of the scale of entrepreneurial activity, an increase of its quality characteristics is carried out in a variety of ways. The first most common method is the spontaneous formation of an entrepreneurial environment in the country (region) (a good example is modern China [1]). Another way is the development by the government of an economic policy that allows involving a wide range of entrepreneurs in the solution of social and economic problems, the implementation of appropriate measures of state regulation of the economy. An example of such effective actions of the authorities is Austria [2].

In most countries of the world, the development of entrepreneurial ecosystems is considered to be a promising direction for the development of entrepreneurship. The concept of "entrepreneurial ecosystem" in recent decades has become firmly established in international management practices, in politics and in scientific use. This term was first used by J. F. Moore in 1993: "entrepreneurial ecosystems condense out of the original swirl of capital, customer interest, and talent generated by a new innovation, just as successful species spring from the natural resources of sunlight, water, and soil nutrients" [3]. This concept is increasingly used in research strategies of organizations and entrepreneurship.

In the Russian Federation, the development of entrepreneurship is actively regulated by the state by establishing a favorable legal regime for the implementation of entrepreneurial and investment activities in the allocated territories and providing state support to specific areas of such activities or to certain entities. This process received additional impetus after the entry into force on March 31, 2015 of Federal Law No. 473-FZ "On the Territories of Advanced Social and Economic Development in the Russian Federation". According to this normative act, a part of the territory of a subject of the Russian Federation, including a closed administrative and territorial entity, is understood as the territory of the advanced social and economic development. In accordance with the decision of the Government of the Russian Federation, a special legal regime for carrying out entrepreneurial and other activities is established with a view to create favorable conditions for attracting investment, ensuring accelerated socio-economic development and creating comfortable conditions to ensure the life of the population.

The territories of accelerated development are not a new phenomenon for Russia and for foreign countries.

In the world, the creation of such territories has a rich history. The Greek island of Delos as early as 166 was declared a free trade zone. Merchants on this island did not pay taxes and duties and were exempted from a number of administrative duties. Then free trade zones began to be created in Rome, China, on the coasts of the Mediterranean and North Seas. Later, a zone of "porto-franco" arose, 
allowing trade with other countries without paying customs duties (Venice, Marseille, Genoa). In the XX century, the regime of "free harbors" appeared. In these "harbors" (Genoa, Marseille, Hamburg, Luebeck, Vladivostok, Batumi), it was possible to import foreign goods without duties and without customs clearance, to store them indefinitely, process and trade them. At the same time, export-production zones arose, in which favorable conditions were created not only for trade but also for other entrepreneurial activities, including production (Hong Kong, Singapore, Aden, Hamburg). At the next round of international cooperation, a new type of territory arose-techno-innovation zones, in which special incentives and privileges were granted to foreign investors (Irish airport Shannon, 1959). The fourth generation (integration type) zones have spread in recent decades in Asia, Latin America, Central and Eastern Europe. For the purpose of the activity, such zones are divided into industrial production zones, free trade zones, export processing zones, zones for accelerated economic development, zones for technical and economic development, and industrial zones.

The first free economic zones Vyborg, Dauria, Kuzbass, Nakhodka, Sadko, Sakhalin, Technopolis Zelenograd, Yantar and free trade zones "Sheremetyevo", "Moscow-Franco-Port", "Franco-Port Terminal" were created in modern Russia in the 90 s of the 20th century by the adoption of subordinate regulatory and legal acts separately for each territory.

The concept of "free economic zone" was introduced into the Law of the RSFSR of July 4, 1991 No. 1545-1 "On Foreign Investments in the RSFSR". Features of the legal regime of foreign investors in the free economic zone were specified in Article 41 of this law. They included a simplified procedure for registering enterprises, preferential tax treatment, reduced rates for land use and other natural resources, as well as granting long-term lease rights for up to 70 years with sublease rights, a special customs regime, a simplified procedure for crossing the border, entry and exit of foreign citizens.

The norm on the free economic zone appeared in the Federal Law of October 13, 1995, No. 157-FZ "On state regulation of foreign trade activities". Article 23 of this law indicated the prospects for the adoption of a federal law on free economic zones. From 1996 to 1999, federal laws were passed with respect to the Special Economic Zones in the Kaliningrad and Magadan regions and the Center for International Business "Ingushetia". These laws determined special regimes for entrepreneurial and investment activities for the residents: tax incentives, application of the free customs zone regime, accelerated and simplified registration procedure, contractual nature of relations in attracting investments.

On July 22, 2005, Federal Law No. 116-FZ "On Special Economic Zones in the Russian Federation" was adopted. The law provided for the creation of four types of special economic zones: industrial-production, tourist-recreational, technology-innovative and port.

Federal Law No. 244-FZ of September 28, 2010 "On the Innovation Center Skolkovo" was the next measure of the Russian authorities to create territories with a special regime for carrying out business activities. A new tool for innovation development was created - an innovation center for which unique rules of functioning were established, up to the specifics of the implementation of medical and educational activities on its territory.

A year later, by separate Federal Law No. 392-FZ of December 3, 2011 "On Territorial Development Zones in the Russian Federation and on Amendments to Certain Legislative Acts of the Russian Federation", a regular form of territory was created with a special regime for carrying out business activities with the aim of raising the economy of the laggards Regions of the country by providing state support to residents.

On November 29, 2014, Federal Law No. 377-FZ "On the Development of the Crimean Federal District and the Free Economic Zone in the Territories of the Republic of Crimea and the City of Federal Significance of Sevastopol" was adopted. A month later, the Federal Law No. 473-FZ "On the Territories of Advanced Social and Economic Development in the Russian Federation" was adopted, which determined the specifics of the legal regulation of the implementation of entrepreneurial and investment activities in the areas of priority social and economic development. July 13, 2015, the Federal Law of the Russian Federation No. 212-FZ "On the Free Port of Vladivostok" is adopted. All three territories (as well as zones of territorial development) belong to the territories of accelerated social and economic development and have similar legal regimes for the implementation of entrepreneurial and investment activities. The applied mechanism of state regulation is aimed at attracting investments and creating additional jobs in the allocated territories.

\section{RESULTS AND DISCUSSION}

In the literature on a strategy, competition and cooperation, the term "ecosystem" was used by a number of authors. R. Adner and R. Kapoor considered the creation of value in innovative ecosystems and noted the need to take into account the structure of technological interdependence in the development of the company's strategy [4]. E. Autio and L. D. $\mathrm{W}$. Thomas write that "too little is known about how firms can actively create, manage and use innovative ecosystems to increase innovation efficiency" [5]. M. Iansiti and R. Levien show that the new dynamics of the entrepreneurial ecosystem affects the strategy, innovation activity and sustainability of the company [6].

In the business literature, the use of the term "ecosystem" is more diverse. C. W. Wessner suggests that ecosystem factors should be taken into account when studying the policy of an entrepreneurial portfolio [7]. M. Kenney and U. Von Burg correlate entrepreneurial ecosystems with regional clusters of entrepreneurs and specialized resources [8]. S. Nambisan and R. A. Baron explore entrepreneurship in innovative ecosystems [9]. S. Zahra and S. Nambisan consider entrepreneurship in global innovation ecosystems [10]. Z. J. Acs, E.Autio, and L. Szerb use an ecosystem approach in characterizing national business systems [11].

Two directions are identified in the study of entrepreneurial ecosystems: one of them examines the 
interaction of business organizations with "innovative ecosystems", on the other - with "regional ecosystems". I.N. Dubina, O.V. Kozhevina, and A.A. Chub combine these trends. First, they rely on the idea of E. Carayannis and D. Campbell on the innovation-entrepreneurial ecosystem (the innovation-entrepreneurial ecosystem is a multi-layered, multimodal and multilateral system that encompasses mutually reinforcing and mutually reinforcing innovative institutions and clusters of knowledge that are based on human and intellectual capital, Formed under the influence of social capital and backed by financial capital) [12]. Then they give their definition of the spatial innovation-entrepreneurial ecosystem, suggesting that it must be viewed as "a complex open dynamic system, within which a specific institutional environment of an adaptive type is formed that takes into account the strategic objectives of the given system and contributes to the activation of the processes of expanded reproduction of innovations, technologies and human capital" 13, p. 7]. As one of the first conceptual models of the spatial innovation-entrepreneurial ecosystem, the authors propose using the triple helix of innovation, which describes the interaction of science, government and business in the implementation of innovation activities [14]. The concept reflects the "turn" from the "industry-state" dyad, dominant in the industrial economy, to an increase in the role of universities and triple spiral interaction in the triad "scienceindustry-state", in which universities manifest themselves not only as generators of knowledge in the classical sense, but also as initiators of innovation [15].

Different authors use different theoretical approaches to study entrepreneurial ecosystems. P.J. DiMaggio and W.W. Powell [16], L.D.W. Thomas and E. Autio [17] use institutional theory, J. Pfeffer and G.R. Salancik apply the theory of resource dependence [18], D.J. Teece - the theory of the framework of industrial organization [19], R.C. Basole [ 20] S. Nambisan and M. Sawhney [21] - network approaches, C.Zott and R. Amit - concept of the business model [22], S. Nambisan and R.A. Baron - cognitive approaches [9]. Researchers of the spatial innovation-entrepreneurial ecosystem suggest using a triple helix of innovation [13].

Differences between entrepreneurial ecosystems and other widely used contextual concepts, such as markets, clusters, industries, value chains, networks are being actively investigated. E. Stam writes: "What the entrepreneurial ecosystem approach has in common with other established concepts - such as clusters, industrial districts, innovation systems and learning regions - is the focus on the external business environment. The approach differs from these concepts by the fact that the entrepreneur, rather than the enterprise, is the focal point. The entrepreneurial ecosystem approach thus begins with the entrepreneurial individual instead of the company, but also emphasizes the role of the entrepreneurship context. Another significant distinction from other economic policy approaches is that the entrepreneurial ecosystem approach not only sees entrepreneurship as a result of the system, but also sees the importance of entrepreneurs as central players (leaders) in the creation of the system and in keeping the system healthy" [23].
The processes of formation of entrepreneurial ecosystems in different countries, including in countries with economies in transition, are being studied [24].

An algorithm for using ecosystems to achieve a competitive advantage is defined [17].

The best strategies and effective business models for participants of entrepreneurial ecosystems are identified [22].

The role of credit organizations, investment companies, venture funds, entrepreneurial universities, business incubators in the creation and growth of entrepreneurial ecosystems is specified [25].

At the same time, the idea that entrepreneurial organizations rarely work in classical markets characterized by market transactions and traditional competition is being pursued, they often function in network structures that play complementary roles to promote new goods and services.

Different authors define the entrepreneurial ecosystem differently. But the entrepreneur has a central place in the entrepreneurial ecosystems and is the core actor in building and sustaining the ecosystem. This view is made explicit in the definition of National System of Entrepreneurship by Z. J. Acs, E. Autio and L. Szerb. “... The dynamic, institutionally embedded interaction between entrepreneurial attitudes, ability, and aspirations, by individuals, which drives the allocation of resources through the creation and operation of new ventures" [11, p. 479]. S. Stam offers a broad definition of entrepreneurial ecosystems as a "set of interdependent actors and factors coordinated in such a way that they enable productive entrepreneurship" [23, p. 1765]. C. Mason and R. Brown set out a definition of entrepreneurial ecosystems as a "set of interconnected entrepreneurial actors, entrepreneurial organizations, institutions and entrepreneurial processes which formally and informally coalesce to connect, mediate and govern the performance within the local entrepreneurial environment" [26, p. 5]. H. Qian, Z. J. Acs and R. R. Stough define entrepreneurial ecosystem as "those economic, social, institutional and all other important factors that interactively influence the creation, discovery and exploitation of entrepreneurial opportunities" [27, p. 561]. B. Spigel believes that "entrepreneurial ecosystems are combinations of social, political, economic, and cultural elements within a region that support the development and growth of innovative startups and encourage nascent entrepreneurs and other actors to take the risks of starting, funding, and otherwise assisting high-risk ventures" [28, p. 50]. E.Autio, S. Nambisan, L.D. Thomas, and M. Wright write: " Entrepreneurial ecosystems are the only cluster type where cluster externalities and clusterspecific structural elements are explicitly organized around the entrepreneurial process of opportunity discovery, pursuit, and scale-up of new ventures (e.g., new venture accelerators, colearning spaces, makerspaces, business angel networks, networking events, and so on) " [29].

The researchers give not only positive assessments of the results achieved in the study of the entrepreneurial ecosystem, but also criticize individual positions. J. Borissenko and R. Boschma write: "The EE (entrepreneurial ecosystem - V.S.) literature aims to explain (ambitious) entrepreneurship from a 
system or ecosystem perspective. It is a rapidly expanding but relatively new literature, although scholars have mentioned similar principles but used different expressions in the past. Based on a literature review, the authors identified a number of weaknesses in the current EE literature: (1) a clear analytical framework is missing that makes explicit what is cause and effect in an EE; (2) it is not always clear in what way proposed elements are connected in an entrepreneurial system, and which interactions matter most; (3) it remains unclear which institutions, and at what spatial scale, have an impact on the structure and performance of EE; (4) EE studies often follow a case study approach of a region but lack a comparative and multi-scalar perspective; (5) the EE literature has adopted a static framework of EE without considering their evolution over time" [30].

In the proposed definitions of the entrepreneurial ecosystem and in critical remarks, it is possible to deepen the approaches to the entrepreneurial ecosystem. At the heart of this advancement of research thought, there is a more accurate understanding of entrepreneurship. First, entrepreneurship is understood as an evolving process: "the concept of entrepreneurship is broadened and fundamental principles of entrepreneurship are complemented at different stages of the development of a market economy» [31, p. 14]. Secondly, entrepreneurship in a developing economy is becoming more and more evident as "an innovative, accompanied by the risk activity of economic entities, consisting in the creation of new capital during the relevant conversion of resources, factors, conditions, forms, methods, means and results of economic activity and to obtain on this basis, the various forms of entrepreneurial income. Entrepreneurship is also carried out as transformation (change of shape, direction, methods of application) with the aim of increase the productivity of capital previously created with the purpose of obtaining business income" [32, p. 2195].

World Economic Forum [25, p. 6-7] allocates available markets, human capital, financing and finance, system support, government policy and regulatory framework, education and training, major universities as catalysts, cultural environment in the structure of entrepreneurial ecosystems as subsystems. Each subsystem, in turn, consists of components. Both subsystems and components work on the main objectives of the entrepreneurial ecosystem - the creation, discovery and use (by generating new capital) of entrepreneurial opportunities.

On the territories of advanced social and economic development in the Russian Federation, the adopted law implies only a partial formation of such subsystems and their elements.

Table 1 shows the subsystems and components of the entrepreneurial ecosystem and the territory of advanced social and economic development.

TABLE I. SUBSYSTEMS AND COMPONENTS OF THE ENTREPRENEURIAL ECOSYSTEM AND THE TERRITORY OF ADVANCED SOCIAL AND ECONOMIC DEVELOPMENT

\begin{tabular}{|c|c|}
\hline Subsyst & Components \\
\hline
\end{tabular}

\begin{tabular}{|c|c|c|}
\hline ems & $\begin{array}{r}\text { Entreprene } \\
\text { urial ecosystem }\end{array}$ & $\begin{array}{l}\text { The territory of advanced social } \\
\text { and economic development }\end{array}$ \\
\hline $\begin{array}{l}\text { Accessi } \\
\text { ble markets }\end{array}$ & $\begin{array}{l}\quad \text { Domestic } \\
\text { market: } \\
\text { Large/medium/s } \\
\text { mall companies } \\
\text { as customers, } \\
\text { governments as } \\
\text { customer } \\
\quad \text { Foreign } \\
\text { market: } \\
\text { Large/medium/s } \\
\text { mall companies } \\
\text { as customers, } \\
\text { governments as } \\
\text { customer }\end{array}$ & $\begin{array}{l}\text { Regulated market with the } \\
\text { participation of the management } \\
\text { company and residents. } \\
\text { The management company is a } \\
\text { joint-stock company, which is defined } \\
\text { by the Government of the Russian } \\
\text { Federation in order to exercise the } \\
\text { functions of managing the territory of } \\
\text { advanced social and economic } \\
\text { development, and one hundred percent } \\
\text { of shares of which belongs to the } \\
\text { Russian Federation, and (or) a } \\
\text { subsidiary economic company created } \\
\text { with the participation of such a joint- } \\
\text { stock company. } \\
\text { Resident of the territory of } \\
\text { advanced social and economic } \\
\text { development is an individual } \\
\text { entrepreneur or a legal entity that is a } \\
\text { commercial organization, the state } \\
\text { registration of which is carried out in } \\
\text { the territory of advanced social and } \\
\text { economic development in accordance } \\
\text { with the legislation of the Russian } \\
\text { Federation (with the exception of state } \\
\text { and municipal unitary enterprises), } \\
\text { which in accordance with this Federal } \\
\text { Law Agreement on the } \\
\text { implementation of activities in the } \\
\text { territory of the leading social } \\
\text { economic development and included } \\
\text { in the register of residents of the } \\
\text { territory of advanced social and } \\
\text { economic development. }\end{array}$ \\
\hline $\begin{array}{l}\text { Human } \\
\text { capital/work } \\
\text { force }\end{array}$ & $\begin{array}{l}\text { Manageme } \\
\text { nt talent, } \\
\text { technical talent, } \\
\text { entrepreneurial } \\
\text { company } \\
\text { experience, } \\
\text { outsourcing } \\
\text { availability, to } \\
\text { access } \\
\text { immigrant } \\
\text { workforce }\end{array}$ & $\begin{array}{l}\text { It is envisaged to attract foreign } \\
\text { workers, including professional } \\
\text { qualification groups, taking into } \\
\text { account the situation on the labor } \\
\text { market of a constituent entity of the } \\
\text { Russian Federation, within the } \\
\text { boundaries of which it is planned to } \\
\text { create a territory for outrunning socio- } \\
\text { economic development, taking into } \\
\text { account the political, economic, social } \\
\text { and demographic situation in this } \\
\text { entity Russian Federation }\end{array}$ \\
\hline $\begin{array}{l}\text { Funding } \\
\& \text { finance }\end{array}$ & $\begin{array}{l}\text { Friends and } \\
\text { family, angel } \\
\text { investors, } \\
\text { private equity, } \\
\text { venture capital, } \\
\text { access to debt }\end{array}$ & $\begin{array}{l}\text { The financial provision of } \\
\text { infrastructure facilities for the territory } \\
\text { of the advanced social and economic } \\
\text { development is carried out at the } \\
\text { expense of the federal budget, the } \\
\text { budget of the constituent entity of the } \\
\text { Russian Federation and local budgets, } \\
\text { as well as extrabudgetary sources of } \\
\text { funding. } \\
\text { Financing the construction, } \\
\text { reconstruction and (or) operation of } \\
\text { infrastructure facilities of the territory } \\
\text { of advanced socio-economic } \\
\text { development at the expense of the } \\
\text { federal budget, the budget of the } \\
\text { subject of the Russian Federation, the } \\
\text { local budget, and extra-budgetary } \\
\text { sources of financing. Use of project } \\
\text { financing mechanisms (legal and } \\
\text { contractual and corporate funds for } \\
\text { financing and organizing a large, }\end{array}$ \\
\hline
\end{tabular}




\begin{tabular}{|c|c|c|}
\hline \multirow{3}{*}{$\begin{array}{l}\text { Subsyst } \\
\text { ems }\end{array}$} & \multicolumn{2}{|r|}{ Components } \\
\hline & $\begin{array}{r}\text { Entreprene } \\
\text { urial ecosystem }\end{array}$ & $\begin{array}{l}\text { The territory of advanced social } \\
\text { and economic development }\end{array}$ \\
\hline & & $\begin{array}{l}\text { long-term investment project that } \\
\text { involves the return of funds invested } \\
\text { by the profits from the implementation } \\
\text { of the investment project). }\end{array}$ \\
\hline $\begin{array}{l}\text { Support } \\
\text { systems / } \\
\text { mentors }\end{array}$ & $\begin{array}{l}\quad \text { Mentors/ad } \\
\text { visors, } \\
\text { professional } \\
\text { services, } \\
\text { incubators/accel } \\
\text { erators, } \\
\text { networks of } \\
\text { entrepreneurial } \\
\text { peers }\end{array}$ & $\begin{array}{l}\text { On the territory of advanced } \\
\text { socio-economic development, objects } \\
\text { forming industrial parks can be } \\
\text { created. } \\
\text { Industrial park is a set of } \\
\text { industrial infrastructure designed to } \\
\text { create industrial production or } \\
\text { modernization of industrial production } \\
\text { and managed by a management } \\
\text { company - a commercial or non-profit } \\
\text { organization established in accordance } \\
\text { with the legislation of the Russian } \\
\text { Federation }\end{array}$ \\
\hline \begin{tabular}{l}
\multicolumn{2}{c}{ Govern } \\
ment \& \\
regulatory \\
framework
\end{tabular} & $\begin{array}{l}\quad \text { Ease } \\
\text { starting } \\
\text { business, tax } \\
\text { incentives, } \\
\text { business- } \\
\text { friendly } \\
\text { legislation/polic } \\
\text { ies, access to } \\
\text { basic } \\
\text { infrastructure, } \\
\text { access to } \\
\text { telecommunicat } \\
\text { ions/broadband, } \\
\text { access to } \\
\text { transport }\end{array}$ & $\begin{array}{l}\text { A special legal regime operates in } \\
\text { the implementation of economic } \\
\text { activities according to the list in } \\
\text { accordance with the annex to the } \\
\text { Decree of the Government of the } \\
\text { Russian Federation on the creation of } \\
\text { a corresponding territory for advanced } \\
\text { social and economic development* }\end{array}$ \\
\hline $\begin{array}{l}\text { Educati } \\
\text { on \& } \\
\text { training }\end{array}$ & \begin{tabular}{l}
\multicolumn{2}{c}{ Available } \\
workforce with \\
pre-university \\
education, \\
available \\
workforce with \\
university \\
education, \\
entrepreneur- \\
specific training
\end{tabular} & $\begin{array}{l}\text { In order to create conditions for } \\
\text { the application of the best foreign } \\
\text { methods and standards of educational } \\
\text { activity, training of employees of } \\
\text { residents of the territory of advanced } \\
\text { social and economic development, the } \\
\text { Government of the Russian Federation } \\
\text { has the right to establish the features } \\
\text { of licensing educational activities of } \\
\text { organizations engaged in educational } \\
\text { activities under vocational training } \\
\text { programs and additional professional } \\
\text { programs on the territory of the } \\
\text { outpacing socio- Economic } \\
\text { development Such territory or being } \\
\text { residents of the territory of advanced } \\
\text { socio-economic development }\end{array}$ \\
\hline $\begin{array}{l}\text { Major } \\
\text { universities } \\
\text { as catalysts }\end{array}$ & \begin{tabular}{l}
\multicolumn{2}{c}{ Promoting } \\
a culture of \\
respect for \\
entrepreneurshi \\
p, playing a key \\
role in idea- \\
formation for \\
new companies, \\
playing a key \\
role \\
providing in \\
graduates to \\
new companies
\end{tabular} & - \\
\hline
\end{tabular}

\begin{tabular}{|c|c|c|}
\hline \multirow{2}{*}{$\begin{array}{l}\text { Subsyst } \\
\text { ems }\end{array}$} & \multicolumn{2}{|r|}{ Components } \\
\hline & $\begin{array}{r}\text { Entreprene } \\
\text { urial ecosystem }\end{array}$ & $\begin{array}{l}\text { The territory of advanced social } \\
\text { and economic development }\end{array}$ \\
\hline $\begin{array}{l}\text { Cultural } \\
\text { support }\end{array}$ & \begin{tabular}{l}
\multicolumn{2}{c}{ Tolerance } \\
for risk and \\
failure, \\
preference for \\
self- \\
employment, \\
success \\
stories/role \\
models, \\
research culture, \\
positive image \\
of \\
entrepreneurshi \\
p, celebration of \\
innovation
\end{tabular} & - \\
\hline
\end{tabular}

*By the Decree of the Government of the Russian Federation No. 629 of June 25, 2015 "On the Establishment of the Territory of the Leading Social and Economic Development" Nadezhdinskaya ", the following conditions are set for the territory of the outstripping social and economic development of Nadezhdinskaya. The territory of advanced social and economic development is created on the territory Municipal entity "Nadezhdinsky municipal district" of the Primorsky Krai. The location of the boundaries is determined by the boundaries of cadastral quarters according to the list established in the annex to the Decision. A special legal regime applies to the implementation of economic activities according to the list in accordance with the annex, in particular: crop production and livestock, hunting, forestry and logging, fishing and fish farming, food production, beverages, tobacco, textiles and clothing, leather and wood products, production of paper, coke and petroleum products, vehicles, furniture, publishing, production of motion pictures, video films and television, research and development, etc. The minimum amount of capital investments of residents of the said Territory is 500,000 rubles. On this territory, the customs procedure of the free customs zone is applied.

The results of comparison of entrepreneurial ecosystems and areas of advanced social and economic development show that in the areas of advanced social and economic development there are no number of important factors and components that contribute to the manifestation of entrepreneurial activity, first of all, the creation of new capital.

\section{CONCLUSION}

The scale of business activity in the world is expanding. In most countries, entrepreneurial ecosystems are successfully formed. The power structures of other countries, including Russia, are trying to accelerate these processes by pursuing an active economic policy. They establish a legal regime in the allocated territories that favors the implementation of entrepreneurial activities. In entrepreneurial ecosystems, active economic entities can freely seek and use favorable opportunities, while creating new capital of various types and forms. In the areas of advanced social and economic 
development, to attract domestic and foreign entrepreneurs, it is necessary to formulate similar conditions.

\section{References}

[1] R.Coase, N. Wang, How China Became Capitalist, Palgrave Macmillan UK, 2012, p. 161 .

[2] O. I. Soskin, "Economic policy for small and medium business in the framework of the model of national capitalism: the Austrian experience", Journal of European Economy, vol. 11(2), pp. 168-184, 2012.

[3] J. F. Moore, "Predators and Prey: a New Ecology of Competition", Harvard Business Review, vol. 71(3), pp. 75-86, 1993.

[4] R. Adner, R. Kapoor, "Value creation in innovation ecosystems: How the structure of technological interdependence affects firm performance in new technology generations", Strategic Management Journal, vol. 31(3), pp. 306-333, 2010.

[5] E. Autio, L. D. W. Thomas, "Innovation ecosystems: Implications for innovation management", in M. Dodgson, D. M. Gann, \& N. Phillips (Eds.), Oxford Handbook of Innovation Management, Oxford, UK: Oxford University Press, 2014, pp. 204-228.

[6] M. Iansiti, R. Levien, The Keystone Advantage: What the New Dynamics of Business Ecosystems Mean for Strategy, Innovation, and Sustainability, Harvard Business School Press, 2004, pp. 221-222.

[7] C. W. Wessner, "Entrepreneurship and the innovation ecosystem policy lessons from the United States", Local Heroes in the Global Village. International Studies in Entrepreneurship, vol 7, Springer, Boston, MA, 2005, pp. 67-89.

[8] M. Kenney, U. Von Burg, "Technology, entrepreneurship and path dependence: Industrial clustering in Silicon Valley and Route 128", Industrial and Corporate Change, vol. 8 (1), 1999, pp. 67-103.

[9] S. Nambisan, R. A. Baron, "Entrepreneurship in innovation ecosystems: Entrepreneurs' self-regulatory processes and their implications for new venture success", Entrepreneurship: Theory \& Practice, vol. 37 (5), pp. 1071-1097, 2013

[10] S. Zahra, S. Nambisan, "Entrepreneurship in global innovation ecosystems", AMS Review, vol. 1 (1), pp. 4-17, 2011.

[11] Z. J. Acs, E. Autio, L. Szerb, "National systems of entrepreneurship: Measurement issues and policy implications", Research Policy, vol. 43 (1), pp. 476-494, 2014.

[12] E. Carayannis, D. Campbell, "Mode 3" and "Quadruple Helix": Toward a 21 st century fractal innovation ecosystem", International Journal of Technology Management, vol. 46 (3-4), pp. 201-234, 2009.

[13] I.N. Dubina, O.V. Kozhevina, A.A. Chub, "Innovation-entrepreneurial ecosystems as a factor of regional development sustainability", Economic Analysis: Theory and Practice, vol. 4, pp. 4-19, 2016.

[14] H. Etzkowitz, L. Leydesdorff, "The Triple Helix: University-industrygovernment relations: A laboratory for knowledge based economic development", EASST Review, vol. 14 (1), pp. 14-19, 1995.
[15] M. Ranga, H. Etzkowitz, "Triple Helix systems: an analytical framework for innovation policy and practice in the Knowledge Society", Industry and Higher Education, vol. 27 (4), pp. 237-262, 2013.

[16] P. J. DiMaggio, W. W. Powell, "The iron cage revisited: Institutional isomorphism and collective rationality in organizational fields", American Sociological Review, vol. 48 (2), pp. 147-160, 1983.

[17] L. D. W. Thomas, E. Autio, "The fifth facet: The ecosystem as organizational field", Innovation and Entrepreneurship Group Working Papers, pp. 1-40, 2014.

[18] J. Pfeffer and G. R. Salancik, The External Control of Organizations, New York, NY, Harper \& Row, 1978.

[19] D. J. Teece, "Explicating dynamic capabilities: the nature and microfoundations of (sustainable) enterprise performance", Strategic Management Journal, vol. 28 (13), pp. 1319-1350, 2007.

[20] R.C. Basole, "Visualization of interfirm relations in a converging mobile ecosystem", Journal of Information Technology, vol. 24, pp. 144-159, 2009.

[21] S. Nambisan, M. Sawhney, "Orchestration processes in network-centric innovation: Evidence from the field", Academy of Management Perspectives, vol. 25 (3), pp. 40-57, 2011.

[22] C. Zott, R. Amit, "Business model design: an activity system perspective", Long Range Planning, vol. 43 (2/3), pp. 216-226, 2010.

[23] E. Stam, "Entrepreneurial ecosystems and regional policy: a sympathetic critique", European Planning Studies, vol. 23 (9), pp. 1759-1769, 2015.

[24] A. Sauka, A. Chepurenko (Eds.), Entrepreneurship in Transition Economies: Diversity, Trends, and Perspectives, Springer, 2017, 444 p.

[25] World Economic Forum, Entrepreneurial Ecosystems Around the Globe and Company Growth Dynamics, Davos, World Economic Forum, 2013.

[26] C. Mason, R. Brown, "Entrepreneurial ecosystems and growth oriented entrepreneurship", Final Report to OECD, Paris, vol. 30 (1), pp. 77-102, 2014.

27] H. Qian, Z. J. Acs, R. R. Stough, "Regional systems of entrepreneurship: the nexus of human capital, knowledge and new firm formation", Journal of Economic Geography, vol. 13 (4), pp. 559-587, 2013.

[28] B. Spigel, "The relational organization of entrepreneurial ecosystems", Entrepreneurship Theory and Practice, vol. 41 (1), pp. 49 72, 2017.

29] E. Autio, S. Nambisan, L. D. Thomas, M. Wright, "Digital affordances, spatial affordances, and the genesis of entrepreneurial ecosystems", Strategic Entrepreneurship Journal, July, 2017.

30] J. Borissenko, R. Boschma, "A critical review of entrepreneurial ecosystems research: towards a future research agenda", vol. 3, Lund University, CIRCLE-Center for Innovation, Research and Competences in the Learning Economy. 2017.

[31] V. Smirnov, "The genesis of the entrepreneurship theory at the classical and non-classical stages of science development", Economic AnnalsXXI, vol. 164(3-4), pp. 14-19, 2017.

[32] V. Smirnov, "Entrepreneurship as the creation of the new capital", Journal of Advanced Research in Law and Economics, vol. VII, 8(22), pp. 2192-2200, Winter 2016. 